\title{
CLINICAL OBSERVATION ON SELF-RECORDING AUDIOMETRY
}

Part I. The fixed frequency self-recording audiometry

$$
\text { By }
$$

\section{S. KOSEKI}

From the Department of Otolaryngology, Faculty of Medicine Hirosaki University (Drector: Prof. S. Katagiri)

The author tested 357 ears in total with normal and impaired hearing, by means of the fixed frequency self-recording audiometry (fixed method), and examined the clinical significance of the amplitude and its type.

As the result the following conclusions were obtained.

1) As the amplitude showed considerable individual variations, it had diagnostic significance clinically only in the case showed small excursion.

2) The increased type of amplitude and TTS were found to have no special significance.

3) In cases of small excursian, especially presented $2 \mathrm{db}$ amplitude, recruitment was thought to exist. However, there were some cases who showed recruitment but presented no small excursion.

4) The fixed method was sufficiently useful as a recruitment test.

\section{自記オージオメトリ一に関する臨床的観察}

第 1 編 固定周波数自記オージオメトリーについて

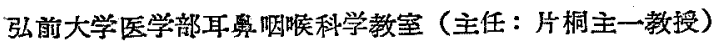

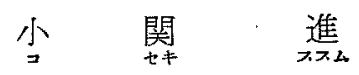

I. 緒言

1947 年 Békèsy 1)により発表された自記オージオメ ーターは，その特異なメカニズム一被検者自身が key を操作しその動きが同時に自動的に聴閵を記録する一の 故に従来の手動式ォージォメーターに見られない多くの 特改を有している.

自記オージォメーターを用いての実䍄及び臨床検查の 成績については，既に多くの報告がありその成績に検討 が加えられているが, 私も亦, 正常者及び各種聴覚障碍 者について，固定周波数及び連続周波数自記オージォメ ーターを用いて検查を行って来た・本編に扎いては，固 定周波数自記オージォメトリー及びその検查成績の持つ 臨床的意羲について険討を如えてみたいと思う。

II. 測定方法

山越製作所製 B-5-RA 型自記オージオメーターを用 いた. attenuation step は $2 \mathrm{db}$. 強さの変化速度は毎 分 $150 \mathrm{db}$. 記録ペンは毎分 $17 \mathrm{~mm}$ の速さで記録台上を
移動し, $250 \mathrm{cps}$ から 8000 sps 迄を10 分 30 秒で記録 する・発振音をある周波数に固定し，その周波数のみで の記録む可能である.

検査の対象は，弘前大学耳鼻科を訪ずれた聴覚障得者 及び正常者, 計 357 耳である・榆查は当教室の防音室内 で行つた。

被検者には，型の如く普通の純音オージオメトリーを 施行し，その後 $1000 \mathrm{cps}$ 㕛はその附近の音で練䍿させ， 検查音及び検查法に対して充分の認識を与兄た後本検查 を行つた。

検查に用いた音は，聴力損失の大なる周波数，伝音性 難聴では主に $1000 \mathrm{cps}$, 感音性難聴では 2000 又は 4000 cps を用い，3〜4 分間記録させ 振楅及び閶佰の変化を 観察した。

\section{III. 検查成績}

自記オージォメーターによるオージオグラムは，言5 迄むなく，上下に鋸籶状つふれを有する带状の曲線で現 
わされる. Békèsy 1) によると，このふれの上下の幅は 強度差弁別間值 Intensity Difference Limen (D.L.) を現わし，Reger ')等はその中点を閶值と考党て良いと 言つている.

この上下のふれの大きさ，即ち振幅，時間の推移によ る自記聴闆の 振幅及び 閾值の変化，振幅と D.L. との 関係について観察した。

\section{1. 振幅の大きさに関する観察}

a）振幅之原因知患との関係

固定周波数自記オージオメトリーによつて得られた振 幅の大きさと難聴原因との関係は，第1表に示寸通りで ある.次に，振幅の大きさにより，2db 以下を繀小型， $3 \mathrm{db}$ 以上 $4 \mathrm{db}$ 迄を移行型, $5 \mathrm{db}$ 以上 $15 \mathrm{db}$ 迄を正常 型， $16 \mathrm{db}$ 以上を堌大型とし，各型の原因別による出現 傾向をみると第 2 表つ如くになる。

縮小型は殆ど感音性難聴にのみ出現して㧊り，2db 振 幅を示掦合は感音性難聴と考光て美支兄ないと思われ る. 移行型に属するものはすべての場合に雉察された

第 1 表 振幅と原因资患

\begin{tabular}{|c|c|c|c|c|c|c|c|c|c|}
\hline \multicolumn{2}{|c|}{ 原因疾振量 $\mathrm{db}$} & 2 & 4 & 6 & 8 & 10 & $4 / 5$ & 16 & 高t \\
\hline \multicolumn{2}{|c|}{ 正常耳 } & & 9 & 20 & 13 & 5 & 1 & 1 & 49 \\
\hline \multirow{4}{*}{$\begin{array}{l}\text { 伝 } \\
\text { 音 } \\
\text { 性 }\end{array}$} & 慢性中耳炎 & & 5 & 7 & 10 & 11 & 1 & 7 & 35 \\
\hline & 耳管新寒症 & & 4 & 8 & 8 & $8^{\circ}$ & $i$ & & 29 \\
\hline & 中耳根治手僻例 & & 1 & 3 & 2 & 7 & & & 7 \\
\hline & 中耳先线貽泟 & & & 1 & 3 & 4 & & 1 & 9 \\
\hline & 小㖕 & & 10 & 19 & 23 & 24 & 2 & 2 & 80 \\
\hline \multirow{3}{*}{ 内 } & 原因不明 & 44 & 26 & 14 & 1 & & & 3 & 88 \\
\hline & SM中毒. & 14 & 5 & $I$ & 2 & & 1 & & 23 \\
\hline & 頭部外傷 & 2 & 6 & 2 & & 2 & & & 12 \\
\hline \multirow[t]{2}{*}{ 耳 } & 音策性外鹪 & 9 & 4 & 5 & 1 & & & & 19 \\
\hline & 突発性㫿聴 & 2 & 1 & 1 & & & & & 4 \\
\hline \multirow[t]{3}{*}{ 性 } & $x=I-ル 氏$ 病 & 3 & 3 & 1 & & & & & 7 \\
\hline & 老人性䔨㮦 & 2 & 4 & 3 & & & & & 9 \\
\hline & ハント氏病 & & & 1 & & & & & 7 \\
\hline \multirow{4}{*}{ 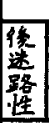 } & 1. 訫 & 76 & 49 & 28 & 4 & 2 & 1 & 3 & 163 \\
\hline & 啮膜类 & & 2 & & & & & & 2 \\
\hline & 胎梅毒 & & & & 1 & 1 & & & 2 \\
\hline & 䏯腰痛 & & & & 2 & & & & 2 \\
\hline & 1. 計 & & 2 & & 3 & 7 & & & 6 \\
\hline \multicolumn{2}{|c|}{ 混合性矔鯰 } & 3 & & 6 & 1 & 1 & & 1 & 12 \\
\hline \multirow{4}{*}{$\begin{array}{l}\text { 其 } \\
\text { 员 } \\
\text { 他 }\end{array}$} & 耳鳴 & 1 & 6 & 6 & 4 & 3 & & 2 & 22 \\
\hline & 眩量感 & & 2 & 1 & 3 & & & & 6 \\
\hline & $S M$ 注射例] & & 2 & 4 & 1 & 2 & & & 9 \\
\hline & 其の他 & & 2 & & 3 & & & & 5 \\
\hline \multicolumn{2}{|r|}{ 小計 } & 1 & 12 & 11 & il & 5 & & 2 & 42 \\
\hline \multirow{3}{*}{$\begin{array}{l}\text { 中 } \\
\text { 柜 } \\
\text { 性 }\end{array}$} & ヒステリ- & & & & & & & 2 & 2 \\
\hline & 抑ラつ应 & & & & & & & 1 & 1 \\
\hline & 耤种薄弱 & & & & & 1 & & 1 & 2 \\
\hline \multicolumn{2}{|r|}{ 小計 } & & & & & $I$ & & 4 & 5 \\
\hline \multicolumn{2}{|r|}{ 計 } & 80 & 82 & 84 & 55 & 39 & 4 & 13 & 357 \\
\hline
\end{tabular}

第 2 表 振幅型と障碍部位

\begin{tabular}{|c|c|c|c|c|c|}
\hline $\begin{array}{l}\text { 振中型 } \\
\text { 部位 }\end{array}$ & 縮小型 & 栘行型 & 正事型 & 増大型 & 計 \\
\hline 正常耳 & & 9 & 39 & I & 49 \\
\hline $\begin{array}{l}\text { 伝意性 } \\
\text { 難㯖 }\end{array}$ & & 10 & 68 & 2 & 80 \\
\hline $\begin{array}{r}\text { 内惟 } \\
\text { 推 }\end{array}$ & 76 & 49 & 35 & 3 & 163 \\
\hline 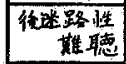 & & 2 & 4 & & 6 \\
\hline $\begin{array}{r}\text { 混畣性 } \\
\text { 推㯖 }\end{array}$ & 3 & & 8 & 1 & 12 \\
\hline 其の他 & 1 & 12 & 27 & 2 & 42 \\
\hline $\begin{array}{l}\text { 中权性 } \\
\text { 雔㯖 } \\
\end{array}$ & & & 1 & 4 & 5 \\
\hline 言十 & 80 & 82 & 182 & 13 & 357 \\
\hline
\end{tabular}

が，感音性難聴あるいは感音性要素を含むと思われる場 合に出現傾问が最も大きい. 正常振幅を示す場合は，正 常者及び盾音性難聴に多いが，又，感音性難聴も少なか らず観察された・増大型も亦殆どすべての場合に観察さ れている。

b）振幅の大きさと聴力損失の程度との閣係

伝音性難聴では第 3 表に示される如く，振幅之聴力損 失の程度との間には特別な関倸は認められないが，感音 性難聴に和いては第 4 表の如く，振幅 4db 以下では一 般に聴力損失の大なるひのが多く，これに対し正常振幅 を示すむのは，聴力損失が中等度以下のるのにやや多く 現われる傾向がみられる・

c）低音及び高音に和ける振幅の差

同一耳に特いても周波数により，特に 低音と 高音と で，振幅に相違ある場合が㕍な観察される。これを 1000 cps 以下の低音と, $2000 \mathrm{cps}$ 以上の高音に分往て比較す

第 3 表 聴力損失と振幅の関保 伝吾性鹳聴

\begin{tabular}{|c|c|c|c|c|c|c|c|c|c|c|}
\hline 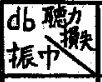 & 0 & 10 & 20 & 30 & 40 & 50 & 60 & 70 & 80 & 計 \\
\hline 2 & & & & & & & & & & \\
\hline 4 & & $!$ & 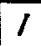 & 2 & 1 & 3 & 2 & & & 10 \\
\hline 6 & & 2 & 8 & 4 & 3 & & 2 & & & 19 \\
\hline 8 & & 2 & 4 & 2 & 6 & 5 & 3 & $I$ & & 23 \\
\hline 10 & 7 & 1 & 3 & 6 & 3 & 6 & 4 & & & 24 \\
\hline 15 以下 & & & & $I$ & & $\cdot$ & 1 & & & 2 \\
\hline 162人1 & & & $I$ & 1 & & & & & & 2 \\
\hline 鼓 & 1 & 6 & 17 & 16 & 13 & 14 & $1 / 2$ & 7 & & 80 \\
\hline
\end{tabular}




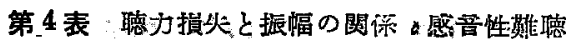
（混合性鹤聴を含も）

\begin{tabular}{|c|c|c|c|c|c|c|c|c|c|c|}
\hline 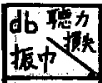 & 0 & 10 & 20 & 30 & 40 & 50 & 60 & 70 & 80 & \\
\hline 2 & 1 & 1 & 5 & 12 & 16 & 9 & 20 & 10 & 5 & 17 \\
\hline 4 & 1 & & 6 & 6 & 6 & 10 & 13 & 8 & 1 & 51 \\
\hline 6 & & & 6 & 4 & 10 & 5 & 5 & 1 & 3 & 34 \\
\hline 8 & & & 2 & 4 & 11 & 7 & & & & 8 \\
\hline 10 & & & 2 & & 11 & 1 & & & & 4 \\
\hline $15 M F$ & & 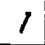 & & & & & & & & 1 \\
\hline 16.4k & & & & 1 & 1 & 2 & & & & 4 \\
\hline 計 & 2 & 2 & 21 & 27 & 35 & 28 & 38 & 19 & 9 & \\
\hline
\end{tabular}

第 5 表 低至及び高至の振幅筇

\begin{tabular}{|c|c|c|c|c|}
\hline & \multicolumn{2}{|c|}{ 感音性藉聴 } & \multicolumn{2}{|c|}{ 伝音性睢俧 } \\
\hline CPS & $\begin{array}{l}1000 \\
3 \times T\end{array}$ & $\begin{array}{l}2000 \\
4 上\end{array}$ & $\begin{array}{l}1000 \\
41 \%\end{array}$ & $\begin{array}{l}2000 \\
42 x\end{array}$ \\
\hline 2 & 8 & 65 & & \\
\hline 4 & 37 & 43 & 4 & 10 \\
\hline 6 & 49 & 25 & 13 & 15 \\
\hline 8 & 30 & 8 & 14 & 11 \\
\hline 10 & 16 & $l$ & 14 & 12 \\
\hline 15 WT & 5 & 1 & 4 & 2 \\
\hline 16 .4上 & 2 & 4 & 1 & \\
\hline 言十 & 147 & 147 & 50 & 50 \\
\hline
\end{tabular}

，と，第 5 表に示す如く，感音性難聴では $2 \mathrm{db}$ 振幅を 活ものは $2000 \mathrm{cps}$ 以上飞非常に多く, 逆に正常振幅 :示すものは $1000 \mathrm{cps}$ 以下に多く観察される.これに しし，伝音性難聴ではこの間に特別な関係は認められな ․この点は感音性及び伝音性觀聴の間の相違を示する と言える。

2. 時間の推移による自記聴闒曲線の変動に

関寸る観察

本法によつて得られた振幅及び閏值の，時間推移によ

変動を観察すると，次の I 〜 VI型の何れか炕分類され

・即ち

I 型 振幅 $5 \mathrm{db}$ 以上 $15 \mathrm{db}$ 以下

I型 振幅 $3 \mathrm{db}$ 以上 $4 \mathrm{db}$ 以下

型 振幅 $2 \mathrm{db}$ 以下

V 型 最初はI型あるいは【 型を示すが，時間の推移 により次第に回型に移行する。

V 型 最初は四型を示すが，時間の推移により次第に 【型あるいはИ型に移行する・
型 振幅 $16 \mathrm{db}$ 以上のるの, 叉は閶値及び振幅が 不規則汇変動するるの.

四型 3 分間の記録で $15 \mathrm{db}$ 以上の間値上昇を示す場 合.

a) 聴間型と障碍部位との関係

その出現傾向を観察すると第6 表の如くであり，I型 第 6 表 聴國型と障碍部位

\begin{tabular}{|c|c|c|c|c|c|c|c|c|}
\hline$\underbrace{\text { 障碍 }}$ & $\begin{array}{l}\text { 正 } \\
\text { 常 } \\
\text { 耳 }\end{array}$ & $\begin{array}{l}\text { 伝 } \\
\text { 音蜼 } \\
\text { 胜骀 }\end{array}$ & $\begin{array}{l}\text { 内 } \\
\text { 耳難 } \\
\text { 栍衈 }\end{array}$ & 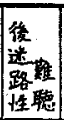 & $\begin{array}{l}\text { 混 } \\
\text { 合䊒 } \\
\text { 性聽 }\end{array}$ & $\begin{array}{l}\text { 基 } \\
\text { 他 }\end{array}$ & $\begin{array}{l}\text { 中 } \\
\text { 枢維 } \\
\text { 性稳 }\end{array}$ & 計 \\
\hline I LUMU & 39 & 64 & 28 & 3 & 8 & 23 & 1 & 166 \\
\hline II numwn & 7 & 7 & 40 & & & 9 & & 63 \\
\hline [I] & & & 65 & & 3 & 1 & & 69 \\
\hline IV & & 1 & 5 & & & & & 6 \\
\hline$\nabla=W W$ & & & 6 & & & & & 6 \\
\hline$\nabla 1$ DMM & 1 & 2 & 3 & & 1 & 2 & 4 & 13 \\
\hline$\nabla^{164}$ & 2 & 6 & 16 & 3 & & 7 & & 34 \\
\hline 言十 & 49 & 80 & \begin{tabular}{|l|}
163 \\
\end{tabular} & 6 & 12 & 42 & 5 & 357 \\
\hline
\end{tabular}

策 7 表 聴閶型と原因啖患

\begin{tabular}{|c|c|c|c|c|c|c|c|c|c|}
\hline \multicolumn{2}{|c|}{ 原因㢍患 型 } & $\mathrm{I}$ & II & III & $\nabla$ & $\nabla$ & $\nabla \mid$ & $\nabla \|$ & 計 \\
\hline & 正常耳 & 39 & 7 & & & & 1 & 2 & 49 \\
\hline & 慢性中耳光 & 27 & \begin{tabular}{|l|l}
3 \\
\end{tabular} & & 7 & & 1 & 3 & 35 \\
\hline 伝 & 耳管獭窄。 & 23 & 3 & & & & & 3 & 29 \\
\hline 首 & 中耳根洽手保例 & 6 & I & & & & & & 7 \\
\hline 性 & 中取类残唄症 & 8 & & & & & 1 & & 9 \\
\hline & 原因不明 & 13 & 22 & 36 & & 6 & 3 & 8 & 88 \\
\hline 内 & SM中秦 & 3 & 5 & 13 & 7 & & & 1 & 23 \\
\hline & 頭部外傷 & 2 & 3 & 2 & & & & 5 & 12 \\
\hline 耳 & 音響性外鹪 & 4 & 2 & 9 & 4 & & & & 19 \\
\hline 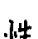 & 突発性難聴 & 1 & 7 & 2 & & & & & 4 \\
\hline & メニエール氏病 & 1 & 3 & 3 & & & & & 7 \\
\hline & 老人性傕㫲 & 3 & 4 & & & & & 2 & 9 \\
\hline & ハント氏病 & 7 & & & & & & & 1 \\
\hline 俊 & 腃膜炎 & & & & & & & 2 & 2 \\
\hline 迷 & 腹梅毒 & 1 & & & & & & 1 & 2 \\
\hline & 腃腫瘟 & 2 & & & & & & & 2 \\
\hline & 合性霍㯖 & 8 & & 3 & & & 7 & & 12 \\
\hline 其 & 耳鳴 & 10 & 5 & 1 & & & 2 & 4 & 22 \\
\hline & 眩量感 & 5 & & & & & & 7 & 6 \\
\hline & SM注射例 & 6 & 2 & & & & & 1 & 9 \\
\hline 他 & 其の他 & 2 & 2 & & & & & 7 & 5 \\
\hline 中 & ヒステリー & & & & & & 2 & & 2 \\
\hline 枢 & 抑ラつ症 & & & & & & 1 & & 7 \\
\hline & 精神㗘弱 & 1 & & & & & 1 & & 2 \\
\hline & 計 & 166 & 63 & 69 & 6 & 6 & 13 & 34 & 357 \\
\hline
\end{tabular}


恪種難聴に 見られるが，殊に正常者及び 伝音性難聴

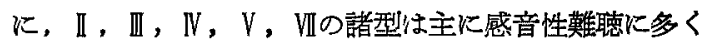

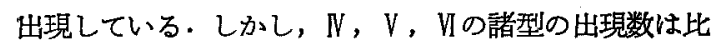
較的少い、これ等諸型を各原因疾患別に細別すると，第 7 表に示す如くである。

\section{b）聴閩型と聴力損失の程度との関保}

伝音性難聴に打いては第8表つ如く，両者の間には特 呺の閏係は認められない，感音性難聴では第9表に示す 如く， II， $\mathrm{V}, \mathrm{V}, \mathrm{V}, \mathrm{V} / \mathrm{l}$ 諸型は聴力損失がある程度 上上になると出現傾问も亦多少多くなるように思われる が，しかし，特別閤係があるとは諗め難い。

第 8 表 聴力摃失と聴閾劦の関係 伝总性難聴

\begin{tabular}{|c|c|c|c|c|c|c|c|c|c|c|}
\hline 歅橾 & $\begin{array}{c}d b \\
0\end{array}$ & 10 & 20 & 30 & 40 & 50 & 60 & 70 & 80 & 計 \\
\hline I & 1 & 5 & 12 & 10 & 12 & 11 & 12 & 1 & & 64 \\
\hline II & & $I$ & 3 & 2 & 1 & & & & & 7 \\
\hline III & & & & & & & & & & \\
\hline 17 & & & & & & 1 & & & & 7 \\
\hline$\nabla$ & & & & & & & & & & \\
\hline$\nabla 1$ & & & & 2 & & & & & & 2 \\
\hline VII & & & 2 & 2 & & 2 & & & & 6 \\
\hline 計 & 1 & 6 & 17 & 16 & 13 & 14 & 12 & 1 & & 80 \\
\hline
\end{tabular}

第 9 表 聴力損失と 聴闌型の関䏡 感牟性離聴 （混合性噍聴を含む）

\begin{tabular}{|c|c|c|c|c|c|c|c|c|c|c|}
\hline 刑型 & $\begin{array}{c}d b \\
0\end{array}$ & 10 & 20 & 30 & 40 & 50 & 60 & 70 & 80 & 計 \\
\hline $\bar{I}$ & & & 8 & 8 & 9 & 6 & 4 & 1 & 3 & 39 \\
\hline$\overline{\text { II }}$ & 2 & 7 & 4 & 6 & 7 & 5 & 8 & 5 & 2 & 40 \\
\hline III & & & 6 & 9 & 13 & 10 & 16 & 10 & 4 & 68 \\
\hline 17 & & & & 1 & $l$ & 2 & 1 & & & 5 \\
\hline$\nabla$ & & & & & 1 & 3 & & 2 & & 6 \\
\hline $\overrightarrow{\nabla 1}$ & & & & 1 & $l$ & 2 & & & & 4 \\
\hline VII & & 1 & 3 & 2 & 3 & & 9 & 1 & & 19 \\
\hline 計 & 2 & 2 & 21 & 27 & 35 & 28 & 38 & 19 & 9 & 181 \\
\hline
\end{tabular}

3. 振幅と D.L. との関係

固定周波数自記による振幅と，Rion A-1013 型ォー ジオメーターの脈音装置（变調周波数 $3 \mathrm{cps}$ ) によつて 得られた閵値上 $10 \mathrm{db}, 30 \mathrm{db} の$ D.L. 值及びその差と の関係を観察した．即や，236耳について得た成績は第 B0, 11，12表に示す通りである.その相関係数はそれぞ
第 10 表 振幅と D.L. との関倸 閶值上 $10 \mathrm{db}$

\begin{tabular}{|c|c|c|c|c|c|c|c|c|}
\hline 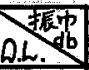 & 2 & 4 & 6 & 8 & 10 & 15 & $4 \frac{41}{16}$ & 計 \\
\hline 0.2 & & 2 & & $I$ & & & & 3 \\
\hline 0.4 & 11 & 5 & 3 & 1 & 1 & & & 21 \\
\hline 0.6 & 26 & 21 & 10 & 1 & 1 & & 2 & 61 \\
\hline 0.8 & 18 & 10 & 7 & 3 & 3 & 1 & & 42 \\
\hline 1.0 & 5 & 6 & 12 & 3 & 1 & & & 27 \\
\hline 1.2 & 3 & 4 & 8 & 6 & 2 & & 2 & 25 \\
\hline 1.4 & 1 & 4 & 4 & 6 & 7 & 1 & 1 & 24 \\
\hline 1.6 & 1 & 1 & 4 & 3 & & & 1 & 10 \\
\hline 1.8 & & 1 & & 5 & 2 & & & 8 \\
\hline 2.0 & & 3 & 2 & & & & & 5 \\
\hline 2.2 & & & 2 & & $I$ & & 1 & 4 \\
\hline \multicolumn{9}{|l|}{2.4} \\
\hline 2.6 & & 1 & 1 & & 2 & & & 4 \\
\hline 2.8 & & & & & & & 1 & 1 \\
\hline 3.0 & & & & & 1 & & & $I$ \\
\hline 言十 & 65 & 58 & 53 & 29 & 21 & 2 & 8 & 236 \\
\hline
\end{tabular}

$r=0.42$

相関め比認められる $\mathrm{r}$ の最小值に 0.138

第 11 表 振幅と D.L.との閣保 闌値上 $30 \mathrm{db}$

\begin{tabular}{|c|c|c|c|c|c|c|c|c|}
\hline 屒中 & 2 & 4 & 6 & 8 & 10 & 15 & 345 & 計 \\
\hline 0.2 & & & & 1 & & & & 1 \\
\hline 0.4 & 13 & 7 & 5 & 2 & & & & 27 \\
\hline 0.6 & 30 & 25 & 18 & 11 & 6 & & 2 & 92 \\
\hline 0.8 & 14 & 16 & 15 & 4 & 8 & 2 & 2 & 61 \\
\hline 1.0 & 2 & 3 & 9 & 6 & 4 & & & 24 \\
\hline 1.2 & 3 & 2 & 4 & 2 & & & 3 & 14 \\
\hline 1.4 & 1 & 4 & 1 & 1 & & & & 7 \\
\hline 1.6 & 2 & & & 2 & 1 & & & 5 \\
\hline 1.8 & & 1 & & & & & & 1 \\
\hline 2.0 & & & & & 1 & & & 1 \\
\hline 2.2 & & & 1 & & & & $I$ & 2 \\
\hline 2.4 & & & & & $I$ & & & 1 \\
\hline 2.6 & & & & & & & & \\
\hline 2.8 & & & & & & & & \\
\hline 3.0 & & & & & & & & \\
\hline 言 & 65 & 58 & 53 & 29 & 21 & 2 & 8 & 236 \\
\hline
\end{tabular}

$\mathbf{r}=0.26$ 
第 12 表 振幅 と D.L. との関傈 閶优上 $10 \mathrm{db}$ の D.L. 值 $\zeta$ 30db の D.L. 值との差

\begin{tabular}{|c|c|c|c|c|c|c|c|c|}
\hline 退 & 2 & 4 & 6 & 8 & 10 & 15 & 16 & $\overline{1}$ \\
\hline-1.0 & & & & & & & & \\
\hline-0.8 & 1 & & & & & & & 1 \\
\hline-0.6 & 1 & & & & & & & 1 \\
\hline-0.4 & 1 & & & 1 & & & & 2 \\
\hline-0.2 & 6 & 6 & 1 & & 2 & & & 15 \\
\hline 0 & 39 & 30 & 16 & 4 & 1 & 1 & 2 & 93 \\
\hline 0.2 & 12 & 8 & 17 & 5 & 2 & & 1 & 45 \\
\hline 0.4 & 3 & 7 & 8 & 9 & 5 & & 4 & 36 \\
\hline 0.6 & 2 & 5 & 5 & 6 & 7 & 1 & & 26 \\
\hline 0.8 & & 1 & 2 & 1 & 1 & & & 5 \\
\hline 1.0 & & 1 & 3 & & 1 & & 1 & 6 \\
\hline 1.2 & & & 1 & 3 & 2 & & & 6 \\
\hline 1.4 & & & & & & & & \\
\hline 1.6 & & & & & & & & \\
\hline $1+2$ & 65 & 58 & 53 & 29 & 21 & 2 & 8 & 236 \\
\hline
\end{tabular}

$\mathbf{r}=0.37$

れ 0.42，0.26，0.37であり，振幅と D.L. 值との間には 特に高度の相関々係があるとは言えない迄も，かなりの 相関々係があるものと考えられる・

\section{IV. 考按}

1. 振幅の大きさについ

自記法による振幅がかなり大きな 個人美を有する事 は，先人諸家の等しく認める奶である. Békésy 1) は振 幅は D.L. を現わすと言つている.しかし，振幅は D. L.のみによつて変化するものではなく，被検者の精神 譏能，注意力，反応時間，慣れ，等に上り影響されると Lundborg 4) む述べている・このような被検者の主観 を左右する種なの原因が，正常者に扎いてす振偪の広い 変動帯をむたらするのと思われる。

正常者の振幅について, Reger ${ }^{2) は, 6 〜 8 d b て ゙ あ り ~}$ この 2 倍の值を示すものは信頼できないと言い，Lundborg4)は, 最小 $5 \mathrm{db}$ 最大 $20 \mathrm{db}$, 大多数は 6〜9db 間にあると言う. Palva 19)によれば 7〜10db が普通 であるが慣れない被検者では時に $5 \mathrm{db}$ 以下の振幅を示 す事がある.Wedenberg 10〉 は多くは 6〜8db と述べ ている. 即ち、上記諸家の観察は，正常者では 6〜10db 以内が最も多いが，例外的に最小 $4 \sim 5 \mathrm{db}$, 最大 $20 \mathrm{db}$
を示す場合がある事を明かにして特り，私の観察成績る ほぼこれ等と一致している。

以上の事を考慮して，観察された振幅を，縮小型には 正常者の変動を除外し得た $2 \mathrm{db}$ 振幅を示した場合のみ を含め, 5〜15db を正常振幅型とし，16db 以上を堌大 型として分類した：この間にあつて，縮小型又正常型何 れと分類しがたい、3〜4db 振幅を移行型とし，4型に 分け検討を試みた。

これ等の型についてなお少しく考察してみると，縮小 型は前述の如く，殆ど感音性難聴にのみ出現しており， 移行型は正常者又伝音性難聴にも見出されるが，感音性 難聴あるいは感音性要素を含むと考えられる場合にかな り筧察される－正常型は，正常者，伝音性難聴がその大 半を占めるが，感音性難聴にる少なからず出現してお り，正常振幅を示す場合でも感音性難聴を否定できない 事を示している・堌大型は少数例ではあるが殆どすべて の疾患に見出され，且中枢性難聴に出現率が高度な事 は，振幅は D.L.のみを示すむのでなく，注意力，反 応力，等の精神的要素に大いに影響される事を暗示して 物り，従つて，このような場合に和いては，振幅の大き さから D.L. を読みとる事は無意味と言えよう。

移行型として分類した 3〜4db 振幅を示すむのは，正 常者及び伝音性難聴にす少ふからず観察されている・立 末は，振幅は大きい万への変動はかなり多いが小さい方 への変動は稀であると述べ, Watson and Tolan ${ }^{1-は ， ~}$ 慣れた紴検者では振幅を極端に小さくする事ができると 言い，又，Palva 12)は，慣れない被袷者では稀に $5 \mathrm{db}$ 以下の振幅を示す事があると述べている・慣れない被侩 者程振幅の変動が大きく，一般に振幅が大に計測され易 い事は日常憠々経験するところであり，本法施行の性質 上振幅大の方への变動が多いの垱然としても，ある場 合には，例光ば，音楽的に訓絣された耳や先天的に鋭敏 な聴覚の所有者に括けるより小さい振幅，あるいは被検 者の主観に基く振幅小の方への変動はありらる事と思わ れる. 正常者及び伝音性難聴で 3〜 4db 振幅を示す埸合 は，恐らく上記のような事に基くものと考えられる・

何れにせよ，正常者文は伝音性難聴にこのような移行 型が比較的多く観察されるのは，感音性難聴に版ける正 常型の存在と共に，本法の振幅による判定をある程度困 難にするるのである。

ここで振幅に関する上述の見解を要約してみると，綃 小型を示するのは感音性難聴に限られ，移行型は大なる 可能性をむつて感音性難聴が考えられる・しかし，正常型 
又は增大型を示す場合でも感音性難聴を否定出来ない。

従つて，臨床上その振幅から直ちに障得部位を推定し 又診断を下し得るのは，2db 振幅を示す場合のみであ ク，それ以外の埸合では，振幅のみからは障碍部位の確 定的な診断を下す事はできないてであるから，振幅の臨 床上の分類は，2db 以下の 振幅とそれ以上の振幅を示 す埸合とに大別するか，又は，大なる可能性で感音性難 聴が考えられる移行型をこの間比設け，2 㕛は 3 型に大 別する程度で充分であり，それ以上の細分化は混乱を招 くのみで分類の意義は少小むのと考兄られる・故に，移

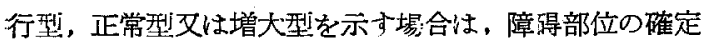
には更に榆討を必要とする京は言う迄もない。

同一耳儿㨟いて，低高 2 音の間で得られた振幅を比較 すると，感音性難聴にのみこの間に特有な羑が見出され た（第 5 表参照).

Palva 11) は，500cps 以下では small excursion は 非常に少い. small excursion 4 4000 6000cps で最 も容易に見られるが，1000 文は $2000 \mathrm{cps}$ でる容易に観 察されると言つており，Wedenberg ${ }^{10)}$ も $500 \mathrm{cps}$ 以 下では recruitment の現れるのは稀で recruitment は 1500cps 以上に多いと述べている. Meurmann5), Palva 12) は，正常者では固定周波数自記による各周波 数の間に振幅の差は見られないか又極めて少い，と言つ ている.

しかし，振幅を比較する場合には，聴力員失の有無を る洘濾すべきであり，感音性難聴はその性質上低音では 聴力損失が無いか，又あっても軽度つ場合が多く，従っ て， recruitment む現れ難く，振幅に招いても small excursion を示さないのる亦当然であると言える・そし て, 感音性難聴で低音では normal excursion, 高音で small excursion を示すのる当然と言兄よう。

そこで，伝音性及び感音性難聴で低音，高音共に20 $\mathrm{db}$ 以上の聴力溳失を有する場合について，更にこの関 係の㰸討を試みた・その成績は第 13,14 表力通りである が，それは第 5 表に見られたのと全く同一の傾向を示 し，感音性難㯖では聴力溳失の有無何わらず，低音で は振幅大，高音では振幅小之計测される傾向を有する事 が明かである．先に振幅つ大きさと聴力損失の程度とは 余り関係がないと述べた・従つて，感音泩難聴に扣い て, 聴力損失の有無に拘わらず低音では振幅大と計測 され易い事は，低音では一般に recruitment が現れ 難い事を示すものであり，この事について Palva ${ }^{11), ~}$ Wedencerg ${ }^{10)}$ も, 低音では small excursion 又 re-
第 13 表 高䡒及び低意の振市美 (㯖力摃失 $20 \mathrm{db}$ 以上) 层畐性難聴 a)

\begin{tabular}{|c|c|c|}
\hline di CPS & $\begin{array}{c}1000 \\
\text { WF }\end{array}$ & $\begin{array}{c}2000 \\
\text { W上 }\end{array}$ \\
\hline 2 & & \\
\hline 4 & 4 & 6 \\
\hline 6 & 10 & 14 \\
\hline 8 & 13 & 8 \\
\hline 10 & 11 & 10 \\
\hline 15 WF & 1 & 1 \\
\hline 16 以上 & & \\
\hline 言十 & 39 & 39 \\
\hline
\end{tabular}

第 14 表 嵪害及び低吾の振幅美 (聴方損失 $20 \mathrm{db}$ 以.上) 惑害性嚇㯖

a)

\begin{tabular}{|c|c|c|}
\hline $\begin{array}{c}\text { CPS } \\
\text { 运P }\end{array}$ & $\begin{array}{c}1000 \\
4 K F\end{array}$ & $\begin{array}{c}2000 \\
4 \times\end{array}$ \\
\hline 2 & 3 & 25 \\
\hline 4 & 22 & 24 \\
\hline 6 & 20 & 10 \\
\hline 8 & 12 & 2 \\
\hline 10 & 3 & 1 \\
\hline 15 WF & & \\
\hline 16 W & 2 & \\
\hline 言† & 62 & 62 \\
\hline
\end{tabular}

b)

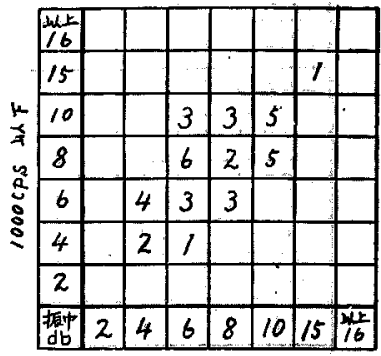

2000ะps 以上

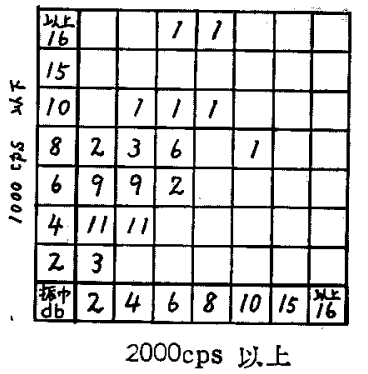

cruitment の現れる事は稀であると述べている.

何れにせよ，聴力損失を考虑しなくても，伝音性難聴 では低音，高音つ振幅有意の羑が認められず，感音性 難聴にのみ有意と思われる差が認められた．この事は， 高音で $2 \mathrm{db}$ 振幅を示す場合は言う迄もないが, 4〜6db 程度の振幅を示す場合でる，低音に抌けるより大きい振 幅との比較により， recruitmen! ありとは断定できない 迄も, recruitment の傾向を，従つて感音性要素の存在 を推定する事ができよう．この事は第1図によつて了解 できる．即ち，500:ps 交ぶ 4000:p3でそれぞれ振愊

第 1 図

\begin{tabular}{|c|c|c|c|}
\hline$C P S$ & 500 & 4000 & \\
\hline \multirow{2}{*}{$\begin{array}{c}\text { 振幅 } \\
\text { d }\end{array}$} & 4 & 4 & $A$ \\
\cline { 2 - 4 } & 10 & 4 & $B$ \\
\hline
\end{tabular}


4db を示した A上りる，500cps では $10 \mathrm{db}$ 振幅であ つたが $4000 \mathrm{cps}$ では $4 \mathrm{db}$ 振幅を示した B に於いて， $4000 \mathrm{cps}$ での recruitment の傾向が推定される.

Bèkésy 1) は，高周波数に拈ける small excursion 恃，低周波数に括ける大きい excursion との比較によ り意味があると述へて打り，固定周波数自記に括いて は，或る1つの周波数の振幅からその意味を考察するよ り，2あるいはそれ以上の異つた周波数での振幅，特に 怟音と高音とを比較する方がより有意義であるらと考え b.

2. -記録時間の推移による閖值及び 振幅の变化を観察 したが，Békésy ${ }^{1)}$ その他が述へている如く，自記オー ジオグラムの聴闒は一定不变である事は少なく，正常者 で恃間の推移に上り, 多少の, $\pm 5 \mathrm{db}$ 位の長波の形 で現れるゆるい動摇が認められる埸合が多い（第2図 a).このような動摇が起る理由として, Palva 1)は, 被㰸者の軽い不注意, レシーバーの位置の変化, 呼吸運 動及び検查室の noise level の変化, 等を挙げている. しかし, Huizing その他の説く 5〜15dbに及ふ心聴閏の 生理的変化に上る事考考えられる.

しかし，2db 振幅を示するのの中には，時間推移によ る閺値変化, 動摇の全く見られない場合が観察される事.

a) $1000 \mathrm{cps}$ 正常耳:

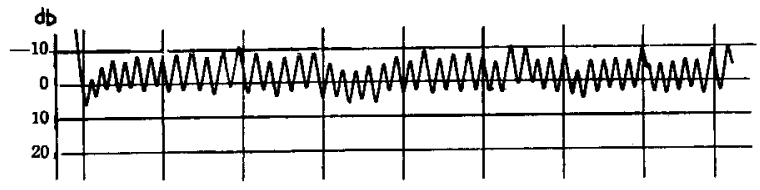

b) $4 \mathrm{COO}=\mathrm{ps}$ 內.耳.性難聴

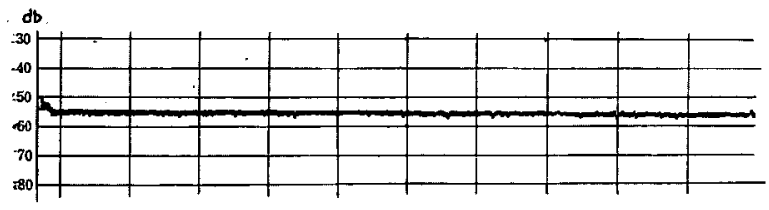

c) 4000 zps 鬲耳-性蜼聴

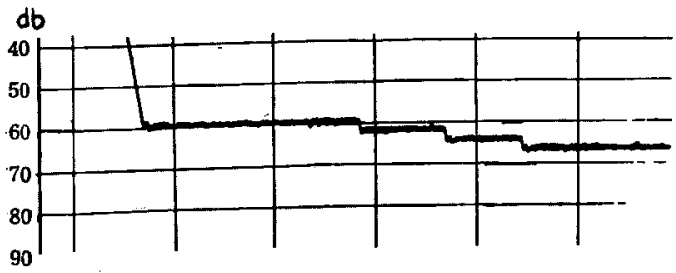

横軼の自盛に゙1目盛が1分間を示す。
がある(第 2 図 b).

しかし，このよらな场合は比較的少なく，多くは前 述の如き酎摇が認められ特见感音性難聴では 5 10db 程度の軽度の闒值上杽をきたす埸合が属々観察される が，2db 振幅を示す筀合即ち，Wedenberg ${ }^{10)}$ の所謂 2 decibel recruitment 又は stroke recruitment $の$ 埸合汇は閏值上昇が段階的に記録される事が少なくない (第 2 図 c).

ここで自記聴闒の型と原因との関係について考察を加 えてみると，I，【I，正型は時間推移による閔値及び振 幅の变動が少い型であり，I型は正常者及び伝音生難聴 に多く，【型は感音性難聴に出現傾向が大きく，四型を 示すものは感音性難聴に特有之言えよら．しかし，I 型 を示す場合でも感音性難聴が，又，刑が正常者及び伝 音性難聴に 観察されている事は振幅の場合と同様であ り， II， II， N型の分類については，振幅の際汇述へた 事と同様な事が言い得ると思う。

$N ， V$ 型のように時間推移により振幅が変化する場合 について, Palva 11) は, 伝音性難聴では 4 分間の記録 で振幅に $\pm 1 〜 2 \mathrm{db}$ の変動があり，感音性難聴では時に 多少振幅が減少する場合があると述べているのみで， N 型に相当する例については立末 ${ }^{9}$ が少数例を報告して いるに過ぎない，私の観察でも，最初型を示したもの がその後の測定では取型を示した例むあり，その

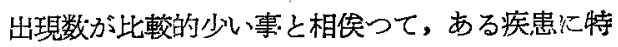
有な型と考えるよりは,むしろ，一種の慣れによ るもの，あるい被祫者の主勧に基くものと考え た方が妥当であろう・これと逆の形を示す V型 は，被検者の倦意，不注意，による事む考光ねば なら妨，検査周波数に類似の耳鳴を訴えた被祫 者が多かつた事は，最初耳鳴と弁別し得た検查音 が次第に耳鳴との弁別が困難になつてきた事が考 えられ，聴覚疲労の一つの型を示するのかる知れ ない.

V型，即ち堌大あるいは不規則な振幅を示す埸合 は，第6,7 表からは疾患に刘する特異性は見出せ す，この上らな場合泣むしろ先述の如く，被検者 の注意力, 反応力, その他の精神的要素の欠如, 正確な応答への努力の意り，等を疑うべきであろ 亏.

VI型は Reger 等 3 の言う temporary threshold shift (TTS) を示す型であり，この型は 3 分間 に $15 \mathrm{db}$ 以上の閾值上昇を示したものである. 
Békésy 1) は，正常者では 15 分間の記録で疲労は認 められないと言い，Reger 等3) る亦同様に，1 時間の 㭘查で $1000 \mathrm{cps}$ では閩值に变化はみられず，4000cps では $5 \mathrm{db}$ の䦪值上昇がみられたに過ぎないと記し， Meurmann ${ }^{5)}$ むBékésy 法では疲労は見出されない と述べている。

一般には確かにこのような現象は起りにくい。しか し，第6，7 表冗示されるように，感音性難聴では勿論の 事，伝音性難聴に括いても，又，少数ながら正常者にも 疲労現象之結びっけられるこの型が観察されて括り，原 因別による特有な出現傾向は認められ難い。

又，このような例につき適当な休止時間を置いて，あ るいは日を改めて再検してみると，その值が初回検查時 のそれに一致しない埸合が要々観察される. 即ち, TTS は常に同一レべルで同じような態度で現れるとは限ら ない。その時の被㭘者つ状態により左右される極めて不 安定な，変動性の多い埸合が少なくない事を意味してお り，このよらに変動性の大きい事は，TTS が純粋な聴 覚の疲労，あるいは順応等により起る場合と，更に，被 棆者の聴覚のみならず精神的あるいは肉体的疲労，不注 意, 倦意，主観，等深支配される場合すある事を意味 するものと考えられる・この事は $\mathrm{V}$ ，V型についても 同様に考えられる・時間推移による振幅の変化, 間值 の変化，が覽察される場合は，これ等の点に充分留意 の上検查を反復して検討を加える事が必要であるら。

しかしこのよらな現象は，臨床的に又聴覚生理上 極めて與味ある事であり，この問題については更に症 例の追加と共に品途㰸討を加えてみたいと思う。

3. 振幅と D.L. との関係について, Bákésy 1) は 本法つ振幅は D.L. を現わすと言い，Reger 2)は threshold excursion は recruitment 発見の最も正 確な且速い測定の方法であると言っている.

立木のは振幅と D.L. 值の間に相関々係を認め， D.L. 值と振幅汢同一基礎を有するものであろうと述 べている. 和が観察した処でも先述の如く相閣る保が 諗められたが，しかし，この両法間には相当のばらつ きが認められた。これは，自記法による振幅及び脈音 によるD.L. 測定值に何れる個人差が大であると言う 事が大い関与しているものと思われる。

D.L. 测定に用いる強さのレべルあるいは判定法に

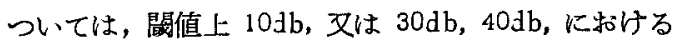
D.L. 值によるか，あるいはこの両者つ D.L. 値の差 により判定すべしとするもの等末だに 定説をみない
が，私は恩地 12)の提唱した方法に従つて判定を下した。 第 $10,11,12$ 表を一見して明かな如く，振幅及び服音値 の相互の関保に怙いてばらつきが多く，変動範囲の広い 事を示している・しかし，2db 振幅を示す場合と，5〜 $15 \mathrm{db}$ の正常振幅を示す場合について，D.L. との閣保 を考察する之第 3，4図に示す如く，2db 振幅を示す場 合は D.L. 值は比較的集中しているが，正常振幅を示す 場合はその分布は広範囲にわたつている・これは闒值上

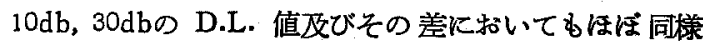
である.従って， $2 \mathrm{db}$ 振幅を示す場合は，恩地の判定 法によると D.L. $(+)$ recruitment 陽性と判定される ものが大多数を占め，D.L. 值と振幅の間には泌接な関 保力認められる。

逆に，D.L. (+) と判定される埸合つ振幅は， $2 \mathrm{db}$ を示す場合が極めて多いが，又 $4 \mathrm{db}$ 振幅を示す場合む 比較的多く観察され，この場合に括いても大体 recruitment の存在を推定して大過ない上5に思われる・これ は， $2 \mathrm{db}$ 振幅を示す場合怕感音性難聴と考えてよいか， 又 $4 \mathrm{db}$ 振幅を示す場合でも感音性難聴に出現傾向が大

第 3 図

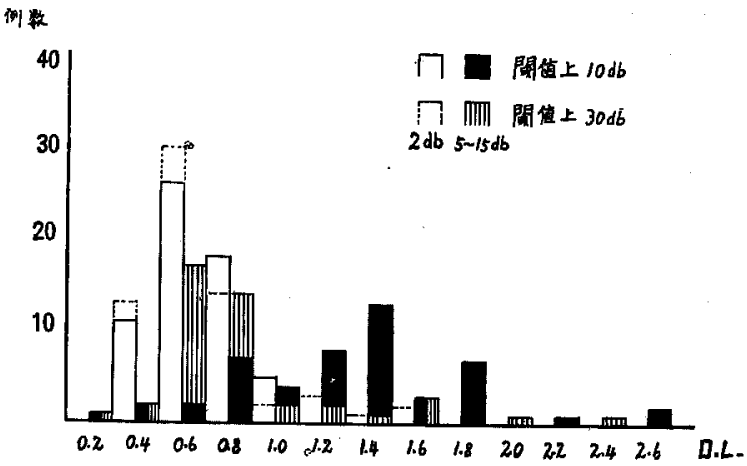

第 4 図

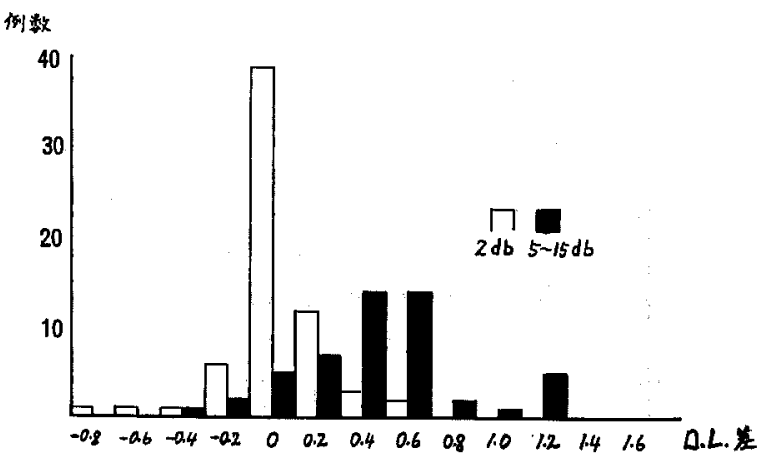


であると述べた前述の見船を裏つける所見であり，D.L. 值と振幅との間の関係において，そのばらつきは振幅の 大きいものが小さいものより大であると言い得る。

及， recruitment の最も確実な indicator である balance test を施行し得た 20 例について，振幅との関 係を考察してみると第 15 表儿示寸通りである・即ち， 注目すべきは balance test で recruitment 陽性と判 定された場合でる， small excursionを示さない場合 が意外多い事であり，自記法による振幅が recruitment の indicator としての役目を果し得ない場合のある 事を示している.

\section{第 15 表}

\begin{tabular}{|c|c|c|c|c|c|c|c|}
\hline $\begin{array}{l}\text { 症例 } \\
\text { No }\end{array}$ & $\left|\begin{array}{r}\text { 内耳性 } \\
\text { 睢聴 }\end{array}\right|$ & $C P S$ & 閶任 & & \begin{tabular}{|l|} 
\\
\end{tabular} & 总例 & $\begin{array}{c}\text { Balance } \\
\text { test }\end{array}$ \\
\hline 29 & 原因不明 & 4000 & 15 & 55 & 6 & 4 & Straightline \\
\hline 44 & 原因不明 & 2000 & 10 & 40 & 8 & 2 & $\begin{array}{l}\text { Straightline } \\
\text { recuint }\end{array}$ \\
\hline 45 & 原，因不明 & 4000 & 10 & 45 & 10 & 2 & $\begin{array}{l}\text { Asymptoti } \\
\text { secrucit }\end{array}$ \\
\hline 54 & 原因不明| & 1000 & 0 & 45 & 10 & 4 & $\begin{array}{l}\text { compalitit } \\
\text { requit. }\end{array}$ \\
\hline 77 & 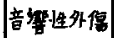 & 2000 & 5 & 55 & 6 & 8 & $\begin{array}{l}\text { Symptotic } \\
\text { Ietcitit. }\end{array}$ \\
\hline 121 & 音響性外暢 & 3000 & 20 & 55. & 4 & 2 & $\begin{array}{l}\text { Straigktlimit. } \\
\text { recusit }\end{array}$ \\
\hline 131 & 原因不明 & 1000 & 15 & 35 & 4 & 6 & $\begin{array}{l}\text { delayess } \\
\text { Recuit }\end{array}$ \\
\hline 154 & 頭部外㑥 & 1000 & 0 & 30 & 10 & 4 & $\begin{array}{l}28 y \text { peptotic } \\
\text { mecruit }\end{array}$ \\
\hline 157 & 原因不明 & 4000 & 0 & 40 & 6 & 8 & $\begin{array}{l}\text { asymptotic } \\
\text { recruit. }\end{array}$ \\
\hline 158 & 原因不明 & 2000 & 5 & 60 & 6 & 4 & $\begin{array}{l}\text { asymptotic } \\
\text { Recruit. }\end{array}$ \\
\hline 181 & 音䇾性外保 & 1000 & 10 & 65 & 6 & 4 & $\begin{array}{l}\text { delayed } \\
\text { 2ecruid }\end{array}$ \\
\hline 183 & 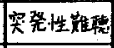 & 1.000 & 10 & 55 & 10 & 8 & $\begin{array}{l}\text { Straightfin } \\
\text { rechuit. }\end{array}$ \\
\hline 192 & 原因不明 & 2000 & 15 & 60 & 4 & 4 & $\begin{array}{l}\text { asymptotic } \\
\text { vechuit. }\end{array}$ \\
\hline 195 & 音響性外偉 & 1000 & 0 & 40 & 8 & 6 & $\begin{array}{l}\text { Straighthine } \\
\text { recruit. }\end{array}$ \\
\hline 232 & 原因不明 & 3000 & 5 & 20 & 4 & 2 & $\begin{array}{l}\text { asymptofic } \\
\text { rechit }\end{array}$ \\
\hline 241 & 原因不明 & 1000 & -5 & 30 & 8 & 4 & $\begin{array}{l}\text { dolayed } \\
\text { sechut }\end{array}$ \\
\hline 245 & |頭部外偈| & 2000 & 0 & 50 & 4 & 2 & $\begin{array}{l}\text { incomples } \\
\text { Rerumit }\end{array}$ \\
\hline 247 & 原因不明 & 1000 & 0 & 30 & 10 & 6 & $\begin{array}{l}\text { asymptotic } \\
\text { recruit. }\end{array}$ \\
\hline 254 & 突発性蜼睡 & 1000 & 0 & 65 & 8 & 4 & $\begin{array}{l}\text { incomplete } \\
\text { Iecrit. }\end{array}$ \\
\hline 274 & \begin{tabular}{|l|} 
原因不明 \\
\end{tabular} & 4000 & 15 & 50 & 6 & 4 & $\begin{array}{l}\text { imcomples. } \\
\text { zeprist. }\end{array}$ \\
\hline
\end{tabular}

自記法による振幅と D.L. 又は recruitment との関 係についての先人諸家の見解は次の通りである。

1) 振幅は D.L. を現わす (Békésy 1), Bangs and Mullins ${ }^{15)}$ ).

2）振幅は常に D.L. 自体を示すむのではない. 又， D.L. のみによつて変動するるのでもない(立木 ${ }^{8)}$ ).

3）振幅は D.L. を現わすとは思えない（Hirsh， Palva ${ }^{11)}$ ).

4) 小さい threshold excursion と recruitment は
同等と考えられる (Dix, Hood, Reger and Cos 3), Reger 2)).

5) 小さい threshold excursion は recruitment $と$ 密接な関係を有する (palva ${ }^{11}$ )).

6) recruitment 陽性例の振幅は縮小型に属する(志 井田 ${ }^{6)}$ ).

振幅は threshold 附近の variability の測定に過ぎ ず D.L.を現わしているとは思われない，との見解を有 する Palva ${ }^{11)}$ ，小さい threshold excursion と recruit ment の間には密接な関係がある事を認めてお り，大多数の研究者は small excursion を示す場合は recruitment の存在を意味するるのと解釈している. しかし，この逆の埸合，振幅が正常籍囲にある時は recruitment の存在を否定できない, normal excursion を示す場合でも， balance test により recruitment が証明される場合がある事を指摘しており，私の観察成 積もこれら諸家の成績とよく一致している。

Palva ${ }^{11)} 27$ 例の recruitment を有する感音性難 聴の中, asymptotic recruitment の例に执いてのみ small excursion を想め, 他の型の recruitment では threshold excursion は正常振幅の 变動箸囲内にあつ たと述べ，Békésy 法でのみ recruitment の有無を評 価すべきでないと言つている。

以上述べてきたように，自記浩の振幅と D.L.值ある いは balance test の成績とは必ずしも一致をみない場 合が往た認められるが，この上らな差は単に個人差ある い測定誤差としてだけの問題であるか，あるいは及， 測定法自体の根本的な相違に由来するものであるのか, 今後更に倹討を要する問題であるう。しかし， small excursion を示す場合は，その殆どに recruntment の 存在を考光得る事は確かである。

\section{V. 䌊 括}

固定周波数自記オージオメトリーによて得られた成績 を観察し，それに検討を加えてきたが，自記オージオグ ラムを評価しその意味を考察する時，先ず考慮せねばな ら事は，本法の象施上の特異性からくるォージオグラ 么の個人差，及びその信頼性と言ら事であるら。

自記オージオグラムは手勘法オージオグラムと異な り，被険者自身により操作され，間值及び振幅が自動的 に記録され険者はただそれを傍観しているの及である。 たとえ予備練習を充分行つたにせ上，ここに被検者つ主 観炕基く誤差が介入する余地があり，こ扎は正常者でも 5 20 tb に及ら゙広い変動帯を示す事でも裹つけけられる・ 
聴覚障淂者ておいいても同様の個人差が認められ，本法に よる判定をある程度困難にし，他の測定法との間の差を 太ならしめる原因となつている事は容易に想像される・

文，自記オージオグラムの信頼性と言う点について は，日常の自記オージオメトリーに扎いて，最初大且不 规則であつた振幅が，被検者の慣れに従つて次第に小さ くなり且安定した trace 学描くに至る事は，多くの被 娭者で㢞々経験するところである・振幅の変動の激しい 埸合（第 5 図 a)，極端に大きい振幅を示す埸合（第 5 図 b）は勿論であるが，又極端に小さい振幅を示す場合 （第5図 c）においても，それが果して丁度聴えた点聴 えなくなつた点に従つて，忠実に key が操作されてい るのか疑わしい時もある。しかし，この場合と，第2図 b， c に示した $2 \mathrm{db}$ recruitment とは，明確に区別せね ばならぬ事・勿論である・

閔值にむいても，前述の如く自記法つ聴閖は必ずしも 一定のものではなく，軽度の動摇が認められるものであ るが(第2図 a,c)，しかし，その闒值が不規則に变動

\section{第 5 図}

a) $1000 \mathrm{cps}$ ヒステリー

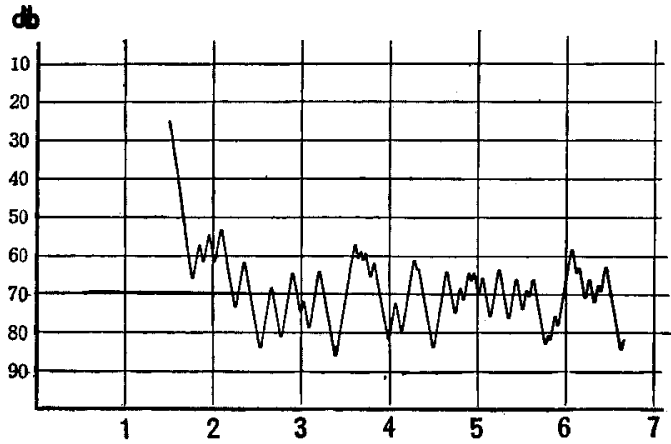

b) $1000 \mathrm{cps}$ 抑 5 つ喊

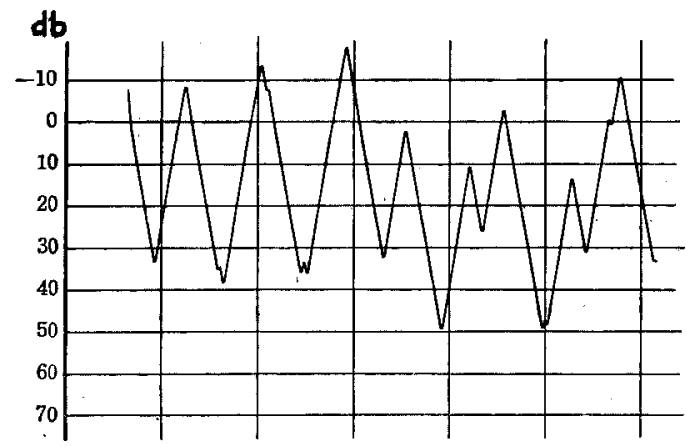

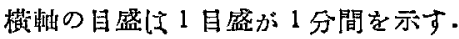

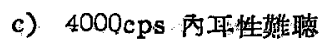

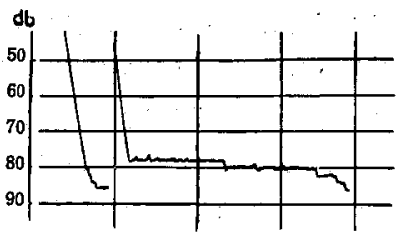

d) $500 \mathrm{cps}$ 內耳性推聴

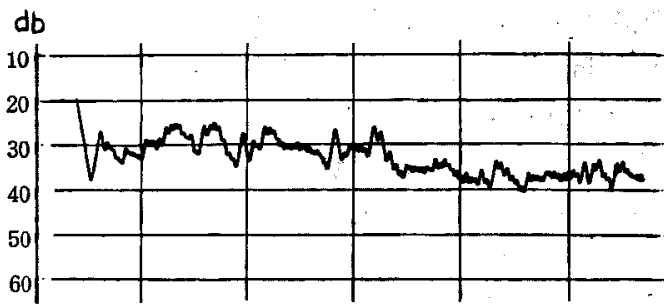

楨軸の目盛红 1 自盛が 1 分·間を示す。

するものとは考えられない(第5図 d).

故に，自記オージオグラムの信頼性は，一般に振幅大 なる時より小なる時, 及び振幅, 閾值の安定した trace を示す際に大であり，逆に，異常に大きい振幅を示す場 合は言う迄もないが，又，極端に小さい振幅を示す時。 あるいは閾值が不定に变動する埸命にもその信頼性は少 いと考えるべきであり，このよらな場合にはその評価に 圥分㣀重でなければならぬ。

上述のように，自記法は振幅の個人差が相当に大であ り，又，オージオグラムの信頼性に閶が持たれる場合 も少くない、しかし，一般の感覚を対象とした検查の常 として，その個人美あるい付誤差はある程度迄避惟い， ものであり，単に本法つ個人差が大，あるいは信頼性が 疑われる場合がある事のみで，その価值が減じられるめ のではなく，特に D.L. 測定法としての本法つ価値を考 察してみると，他の D.L.测定法と比較しても決して㸓 るものではなく，閶值上の強さの音は必要とせず，ただ その間值を测定しさえすれば D.L. が測定される事は， 他つ D.L. 測定法つ追随を䛨さない優れた点である。

上述の成績は，特定の周波数の限られた部分での湘定 結果でありこれらの data から結論を下寸事は避けね ばならぬ場命もある・しかし，固定周波数自記オージオ メトリーは一つの聴覚検查法として, 特に recruitment test として充分用いられる価値のあるものであると思 5 .

要するに，充分な予備練習により可及的に個人差，誤 
差を少なくし且オージォグョムの信頼性を高めるように 努力する事が，本法の価值をより大にするるのである。 VI. 結 諭

1. 振幅にはかなりの個人差が認められ，臨床的に診 断上の意跦を考察しらるのは $2 \mathrm{db}$ 振幅を示す場合のみ である・

2. $2 \mathrm{db}$ 振幅を示すものは感音性䓵衈德特有であり， recruitment を有するむのと考えられる・

3. 正常振幅文は増大振幅を示寸場合は，それのみか ら障碍部位の診断を下す事はできす，又，recruitment の杏定むできない.

4.TTS を示す型は原因疾患と関係なしに見出され te.

5. 固定周波数自記オージオカトソーは recruitment test として充分用いらる検查沠である。

\section{文献}

1) Békésy: Acta Otolaryng., 35; 411, 1947. 2) Reger: Laryngoscope., 62; 1333, $1952 . \quad$ 3) Reger and Cos: Ann. O.R.L., 61;810, 1952. 4) Lun- dborg: Acta Otolaryng.. Suppl. 99, $1952 . \quad$ 5) Meurmann: Acta Otolaryng., Suppl. 116, 1954. 6) 志井田：耳䐅, $27 ; 5,241$, 炤 30.7 7) 立木:

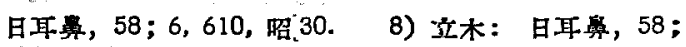
10,1124 , 炤 30 .9Y立本：日耳莮，59；4,487, 炤 31. 10) Wedenberg: Acta Otalaryng., Suppl. 94, 1951. 11) Palva: Laryngoscope., 66; 1519. 1956. 12) Palva: Arch. Otolaryng., 65; 591, 1957. 13）恩地：耳䐅， $25 ； 13,606$ ，炤 28，，14） Watson and Tolan: 交献 7 上订问用. 15) Bangs and Mullins: Arch. Otolaryng., 58; 582, 1953.

稿を終るに臨み，御指薄御校閔を睗わつた恩

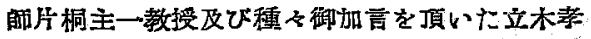
助教授に゙心から感謝します。

本論文の一部【昭和 32 年 9 月 29 日第 7 回東 北岩手地方会連合学会で発萩した。

（原稿到着 $=$ 昭和 33.12.23 日） 